\title{
Identification of Two Additional Susceptibility Loci for Inflammatory Bowel Disease in a Chinese Population
}

\author{
Xiucai Lan ${ }^{a, b}$ Xiuhua Lan ${ }^{c}$ Ying Changa, Xiaomin Zhang ${ }^{a, b}$ Jing Liu ${ }^{a, b}$ \\ Vikash Vikash ${ }^{d}$ Wei Wange Meifang Huang ${ }^{a, b}$ Xiaobing Wang ${ }^{a, b}$ Feng Zhou ${ }^{a, b}$ \\ Liping Chen ${ }^{\mathrm{a}, \mathrm{b}}$ Qiu Zhao ${ }^{\mathrm{a}, \mathrm{b}}$
}

\begin{abstract}
aDepartment of Gastroenterology, Zhongnan Hospital of Wuhan University, Wuhan, 'DThe Hubei Clinical Center \& Key Laboratory of Intestinal \& Colorectal Diseases, Wuhan, cPathology Department, Center for Drug Safety Evaluation and Research, Shanghai Institute of Materia Medica, Chinese Academy of Sciences, Shanghai, dDepartment of Gastroenterology, Renmin Hospital of Wuhan University, Wuhan, Hubei, eDepartment of Gastroenterology, The Sixth Affiliated Hospital of Zhongshan University, Guangzhou, P.R. of China
\end{abstract}

\section{Key Words}

ZMIZ1 • TP53 • TNFSF15 • TL1A • IBD • Polymorphism

\begin{abstract}
Background/Aims: To investigate the associations between the rs1250569 (zinc finger MIZtype containing 1, ZMIZ1), rs1042522 (tumour protein p53, TP53), and rs10114470 (tumour necrosis factor-like cytokine $1 \mathrm{~A}, \mathrm{TL} 1 \mathrm{~A}$ ) polymorphisms and the development of inflammatory bowel disease (IBD) in a Chinese (Han) population. We analysed the expression of genes that predispose patients to Crohn's disease (CD) and ulcerative colitis (UC). Methods: A total of 381 IBD patients and 517 healthy controls were recruited into our study. Polymorphisms at the three loci were genotyped using polymerase chain reaction-ligation detection reactions (PCR-LDR). Genotype-phenotype correlations were analysed. Blood and gut samples were obtained and analysed using quantitative real-time PCR (qRT-PCR), western blot analysis, and immunohistochemistry to investigate the mRNA and protein levels and in situ expression of genes found to predispose patients to IBD. Furthermore, the expression of susceptible genes was further verified using a mouse dextran sulphate sodium (DSS)-induced acute colitis model. Results: No significant association was detected between rs1250569 and rs1042522 genotypes and CD or UC susceptibility. However, the frequency of allele A of rs1250569 was much higher in CD patients than that in healthy controls $(55.03 \%$ vs. $48.48 \%$, respectively; $p=$ 0.044). The mutation rates at rs 10114470 were dramatically lower at both the genotype and allele level in patients than those in healthy controls $(p=0.002$ at both the genotype and allele level). Additionally, increased ZMIZ1 and TL1A levels were detected in intestinal samples obtained from both IBD patients and DSS-treated mice. Conclusion: rs1250569 (ZMIZ1) and rs10114470 (TL1A) are two novel loci that indicate susceptibility to IBD in Han-Chinese patients. Consistent with previous studies, TL1A expression levels were higher in Chinese Han
\end{abstract}


IBD patients and DSS-treated mice. Most importantly, we found that ZMIZ1 expression was markedly higher in both IBD patients and mice with experimentally induced colitis, suggesting that ZMIZ1 plays important roles in the pathogenesis of IBD.

(C) 2017 The Author(s)

Published by S. Karger AG, Basel

\section{Introduction}

Inflammatory bowel disease (IBD) includes ulcerative colitis (UC) and Crohn's disease (CD) and is an intractable disease that is characterised by recurring, relapsing, and remitting episodes of inflammation [1]. According to many studies, the incidence and prevalence of IBD are rapidly increasing worldwide [2, 3]. However, its aetiology remains poorly understood. The event that initiates the development of IBD can be bacterial, viral, or environmental in nature or involve another factor [4-6]. The genetic epidemiological data clearly implies that susceptibility to the pathogenesis of IBD is inherited, and up until now, more than 163 genes have been identified as potential culprit genes in IBD $[7,8]$.

Recently, an immuno-chip analysis of a Korean population identified rs1250569 in zinc finger MIZ-type containing 1 (ZMIZ1) as a novel susceptibility locus for Crohn's disease that increased susceptibility in an Asian population [9].rs1042522, in tumour protein p53 (TP53), has previously been observed in a variety of cancers and associated with an increased risk of IBD in Canadians [10]. TNFSF15 or TL1A (tumour necrosis factor superfamily member 15 and TNF-like cytokine $1 \mathrm{~A}$, respectively) is expressed at significantly higher levels in both CD and UC patients and is well-known to predispose patients to CD and UC around the world [1114]. Moreover, many TL1A loci are associated with IBD susceptibility across all ethnic and age groups $[11,15,16]$. rs10114470 is a novel TL1A locus that was found to provide significant protection against both CD and UC in an Indian population [17]. However, the relationship between rs1250569, rs1042522, and rs10114470 variants and IBD susceptibility has not yet been investigated in a Chinese population. In our study, we found an association between IBD and each of the rs1250569 and rs10114470 variants, but not rs1042522. In addition, higher expression levels of ZMIZ1 and TL1A were detected in IBD patients. A DSS-induced mouse colitis model was used to confirm these results, and high expression levels of ZMIZ1 and TL1A were also observed in DSS-treated mice.

\section{Materials and Methods}

\section{Ethical statement for human samples}

This study was approved by the ethics committee of Zhongnan Hospital of Wuhan University and conducted according to the principles of the Declaration of Helsinki [18]. All participants provided written informed consent before they were included in the study.

\section{Patients and sample collection}

A total of 381 IBD patients (179 with CD and 202 with UC) and 517 healthy controls (age- and gender-matched) were recruited from the Department of Gastroenterology at Zhongnan Hospital of Wuhan University (Wuhan, China) from September 2014 to January 2016. All included patients were evaluated to obtain diagnostic criteria, including clinical, standard endoscopic, radiologic, and histopathological findings [19]. The controls were selected from healthy volunteers at the same time. Lithium sulphate anti-coagulated peripheral blood samples were collected from the patients and healthy controls. The demographic data and clinical characteristics of all of the participants are summarised in Table 1. The clinical features of CD and UC were classified using the Montreal classification criteria [20]. Inflamed colonic biopsies were collected from inflammatory sites adjacent to ulcerations in CD and UC patients who underwent endoscopy at Zhongnan Hospital of Wuhan University. Normal colonic mucosa samples that were collected from healthy volunteers or non-inflamed colon tissues that were 20 centimetres distant from polyps or neoplasms (non-IBD, or NIBD) served as the control tissues. 


\begin{tabular}{|c|c|c|c|c|}
\hline \multirow{26}{*}{$\begin{array}{l}\text { Table 1. Demographic } \\
\text { and sub-phenotype } \\
\text { data of IBD patients } \\
\text { and controls. yr: year. } \\
\text { GI: Gastrointestinal }\end{array}$} & Variable & $\begin{array}{c}\mathrm{CD}(\mathrm{N}=179) \\
(\mathrm{N} \%)\end{array}$ & $\begin{array}{c}\mathrm{UC}(\mathrm{N}=202) \\
(\mathrm{N} \%)\end{array}$ & $\begin{array}{l}\text { Controls }(\mathrm{N}=517) \\
(\mathrm{N} \%)\end{array}$ \\
\hline & Gender & & & \\
\hline & Male & $112(62.57)$ & $113(55.94)$ & $271(52.42)$ \\
\hline & Female & $67(37.43)$ & $89(44.06)$ & $246(47.58)$ \\
\hline & Age (yr) & & & \\
\hline & Mean $\pm S D$ & $34.90 \pm 14.20$ & $41.50 .0 \pm 14.55$ & $38.95 \pm 13.87$ \\
\hline & Range & $13-83$ & $16-80$ & $17-82$ \\
\hline & Age at diagnosis (yr) & & & \\
\hline & Mean \pm SD & $30.57 \pm 13.41$ & $38.01 \pm 13.60$ & \\
\hline & $<17$ & $16(8.94)$ & $4(1.98)$ & \\
\hline & $17-40$ & $125(69.83)$ & $102(50.50)$ & \\
\hline & $>40$ & $38(21.23)$ & $96(47.52)$ & \\
\hline & Site of disease & & & \\
\hline & L1 Ileal & $47(26.26)$ & & \\
\hline & L2 Colonic & $56(31.28)$ & & \\
\hline & L3 Ileocolitis & $71(39.66)$ & & \\
\hline & L4 Upper GI & $5(2.79)$ & & \\
\hline & Disease behavior & & & \\
\hline & B1Non-stricturing/ non-penetrating & $119(66.48)$ & & \\
\hline & B2 Stricturing & $39(21.79)$ & & \\
\hline & B3 Penetrating & $21(11.73)$ & & \\
\hline & Perianal disease & $26(14.53)$ & & \\
\hline & Disease location & & & \\
\hline & E1 Proctitis & & $25(12.38)$ & \\
\hline & E2 Left-sided & & $78(38.61)$ & \\
\hline & E3 Extensive & & $99(49.01)$ & \\
\hline
\end{tabular}

\section{Animals and ethics statement}

Balb/c mice aged 8 to 10 weeks old with a body weight of 20-22 g were obtained and bred under specific pathogen-free (SPF) conditions. They were provided access to food and water ad libitum. The mice were acclimated to the conditions for more than five days before the beginning of the experiments. We performed our experiments in strict accordance with the Chinese laws of protection, and all experimental procedures received approval from the Animal Welfare Committee of Wuhan University.

DSS-induced colitis model

Colitis was induced using dextran sulphate sodium (DSS, MW 36,000-50,000, MP Biomedicals, Solon, $\mathrm{OH}$ ) dissolved in drinking water at a concentration of $4.5 \%$. DSS was provided for seven days. The control group mice were provided with distilled water throughout the experiment. All animals were monitored on a daily basis for any signs of disease, including loss of body weight, stool consistency, occult blood and gross rectal bleeding, by a trained and blinded observer. A disease activity index (DAI) was calculated, as described by Cooper et al. [21]. On day 7, the experimental and control mice were sacrificed using $\mathrm{CO}_{2}$ inhalation and then cervical dislocation. During the autopsy, colon length was measured, and it was gently cleared of faeces using $4{ }^{\circ} \mathrm{C}$ normal saline. Small segments of the distal colon were collected for histopathological analysis and subsequently fixed in 4\% paraformaldehyde (PFA). The remaining colon tissues were reserved for further analysis.

\section{DNA extraction and polymorphism genotyping}

Genomic DNA was extracted from peripheral blood using a DNA blood mini kit (TIANGEN, Beijing) according to the manufacturer's instructions. The genotypes for rs1250569, rs1042522, and rs10114470 were detected using the polymerase chain reaction-ligation detection reaction (PCR-LDR) method with technical support from Shanghai Biowing Applied Biotechnology Company (Shanghai, China) [22, 23]. The primers and probes that were used are shown in Table 2.

\section{RNA extraction and quantitative Real-Time PCR ( $q R T-P C R)$}

Total RNA was extracted from human blood and human or mouse colon samples using Trizol reagent (Invitrogen, USA) according to the manufacturer's protocols. The RNA samples were quantified using a NanoDrop 2000 spectrophotometer (Thermo Scientific, USA). Total RNA (1 $\mu \mathrm{g}$ ) was used to synthesise firststrand cDNA using a synthesis kit (Thermo Scientific, USA). qRT-PCR was subsequently performed using a QuantStudio ${ }^{\mathrm{TM}} 6$ Flex Real-Time PCR instrument (ABI, USA) with SYBR ${ }^{\circledR}$ Premix Ex Taq ${ }^{\mathrm{TM}}$ II mix (Takara, Japan). The gene-specific primer pairs that were used in these experiments are listed in Table 2. 
Lan et al.: Two Novel Susceptible Loci for IBD in a Chinese Han Population

Table 2. Sequences of primers and probes used in the article

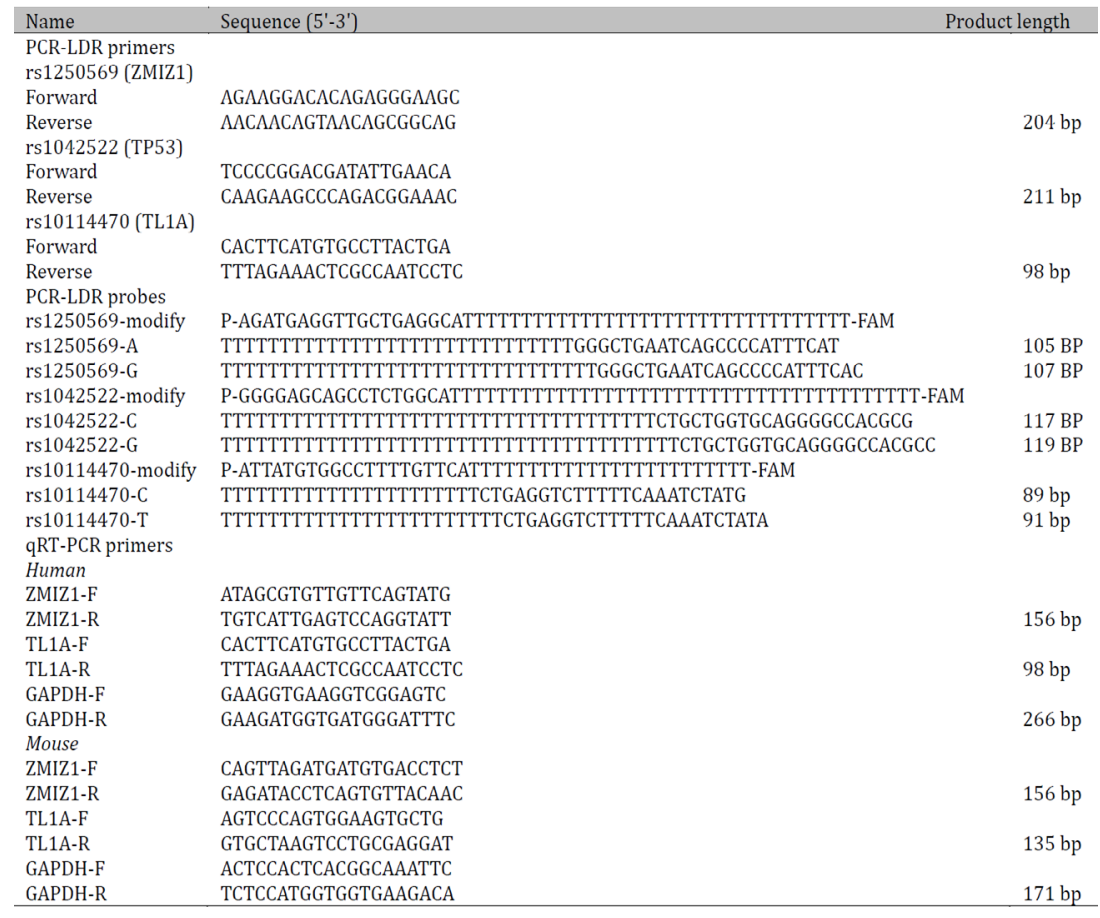

Table 3. Scoring for the severity of histological damage. Scores were calculated by multiplying the score for the first three parameters by their percentage involvement, resulting in a maximum score of 40

\begin{tabular}{lll}
\hline Feature & Score & Description \\
\hline Severity of inflammation & 0 & None \\
& 1 & Mild \\
& 2 & Moderate \\
& 3 & Severe \\
Extent of inflammation & 0 & None \\
& 1 & Mucosa \\
& 2 & Mucosa and submucosa \\
& 3 & Transmural \\
Crypt Damage & & \\
& 1 & $1 / 3$ damaged \\
& 2 & $2 / 3$ damaged \\
& 3 & Crypts lost, surface epithelium present \\
Percentage Involvement & 4 & Crypts and surface epithelium lost \\
& 0 & $0 \%$ \\
& 1 & $1-25 \%$ \\
& 2 & $26-50 \%$ \\
& 3 & $51-75 \%$ \\
& 4 & $76-100 \%$ \\
\hline
\end{tabular}

SDS-polyacrylamide gel electrophoresis (PAGE) and Western blot analysis

Total protein was extracted from human or mouse colon tissues using RIPA lysis buffer supplemented with protease and phosphatase inhibitors. Protein concentrations were determined using a BCA protein assay kit (Beyotime Biotechnology, Shanghai, China). A total of $40 \mu \mathrm{g}$ of protein was loaded onto and separated using an 8\% SDS-PAGE gel. It was then transferred onto polyvinylidene difluoride (PVDF) membranes (Millipore, USA) using a wet transfer apparatus. The membranes were then blocked in TBST (Tris-buffered saline containing $0.1 \%$ Tween-20) containing 5\% non-fat milk powder for $1 \mathrm{~h}$ at room temperature. They were subsequently incubated with specific primary antibodies overnight at $4^{\circ} \mathrm{C}$. After three washes in TBST, the membranes were incubated with horseradish peroxidase (HRP)-conjugated species-specific secondary antibodies for $2 \mathrm{~h}$ at room temperature. After the blots were washed three times 


\section{Cellular Physiology Cell Physiol Biochem 2017;41:2077-2090

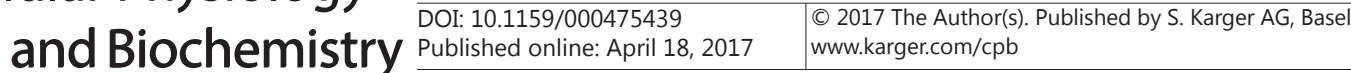 \\ Lan et al.: Two Novel Susceptible Loci for IBD in a Chinese Han Population}

with TBST, they were visualised using high-sensitivity chemiluminescence. The densities of the blots were analysed using Quantity One software (Bio-Rad). Then, the specific protein expression levels of the blots on the membrane were normalised to GAPDH levels. The following primary antibodies were used: anti-ZMIZ1 (human) monoclonal antibody (mAb) (Cat. SC-376825, Santa, USA), anti-TL1A (human/mouse) polyclonal antibody (pAb) (Cat. ab 85566, Abcam, USA), and anti-ZMIZ1 (mouse) mAb (Cat. 37868, Signaway Antibody, China). The antibodies against GAPDH (Cat. KM9002, Sungene, Tianjin, China) and the HRP-conjugated goat anti-rabbit/mouse antibodies (Cat. LK2001/LK2003, Sungene, Tianjin, China).

\section{Histological analysis and immunohistochemistry (IHC)}

Human and mouse colon biopsies that were obtained for histopathology were fixed using 4\% PFA at $4^{\circ} \mathrm{C}$ overnight and then embedded in paraffin. They were cut into $3 \mu \mathrm{m}$-thick paraffin sections and stained using haematoxylin and eosin (H\&E). Histological scoring of the mouse colons was performed in a doubleblinded manner and based on a combination of epithelial damage and inflammatory cell infiltration (Table 3). To perform IHC, the sections were incubated in series with the indicated primary antibodies overnight at $4^{\circ} \mathrm{C}$ and then with species-specific secondary antibodies for 1 hour at room temperature. The following primary antibodies were used: anti-ZMIZ1 (human) pAb (Cat. AP6236a, ABGENT, China) and anti-ZMIZ1 (mouse) mAb (Cat. 37868, Signaway Antibody, China). Sections that were treated with phosphate-buffered saline (PBS) instead of primary antibody were used as negative controls. Images were captured using a microscope (Olympus, Cat. \#IX73). Image-Pro Plus version 6.0 (Media Cybernetics, BetheSEMa, MD) was used to calculate the integrated option density (IOD) of the protein expression.

\section{Statistical analysis}

Hardy-Weinberg calculations were performed, and the 3 single nucleotide polymorphisms (SNPs) were found to be in allelic population equilibrium ( $p=0.32$ for $\operatorname{rs} 1250569, p=0.64$ for rs1042522 and $p$ $=0.39$ for rs10114470). All analyses were performed using SPSS Version 17.0 (Chicago, IL). $\chi 2$ tests were used to analyse genotype and allele frequencies and the genotype-phenotype correlations between the patients and healthy controls. Odds ratios (ORs) and 95\% confidence intervals (CIs) were used to estimate the relative risk of developing CD or UC. Differences in mRNA and protein expression between the patient and control groups were analysed using one-way analysis of variance (ANOVA). Unpaired t-tests were used to analyse the differences between the experimental and control mice. A $p$-value $<0.05$ was considered statistically significant. All data are presented as the mean \pm SD. Representative data are shown for three independent experiments.

\section{Results}

The association between gene polymorphisms and IBD development

The association between the genotypes and IBD susceptibility is illustrated in Table 4. At locus rs1250569, we found that 376/517 (72.73\%) of the healthy controls possessed mutant genotype AA or AG. This was lower than the proportion in the CD $(141 / 179,78.77 \%)$ and UC $(150 / 202,74.26 \%)$ groups, but the difference was not significant ( $p=0.111$ for CD and $p=0.677$ for UC). At the allelic level, the rs 1250569 mutant allele A was a potentially riskassociated locus for $\mathrm{CD}(p=0.044, \mathrm{OR}=1.282,95 \% \mathrm{CI}: 1.007-1.632)$, whereas rs10114470 was a protective locus for $\mathrm{CD}$ at both the genotype and allele level $(p=0.002$, $\mathrm{OR}=0.552$, 95\% CI: 0.381-0.799 for genotype level; $p=0.002$, OR $=0.688,95 \%$ CI: $0.540-0.877$ for allele level). There was no association between the rs1042522 polymorphism and IBD ( $p>0.05$ for CD; $p>0.05$ for UC).

The associations between gene polymorphisms and disease phenotypes are listed in Table 5. In patients possessing rs1250569 mutant genotypes, CD tended to have an early onset ( $p=0.032$, OR $=1.375,95 \% \mathrm{CI}: 1.304-1.450)$. Additionally, CD patients carrying wild type rs10114470 were less likely to suffer intestinal stricture $(p=0.019, \mathrm{OR}=0.439,95 \%$ CI: $0.216-0.890)$ or penetration ( $p=0.001, \mathrm{OR}=0.268,95 \% \mathrm{CI}: 0.115-0.623$ ) and less likely to develop inflammation involving the anus ( $p=0.009$, OR $=0.366,95 \%$ CI: $0.167-0.803)$. Limited correlations were found between the rs1250569 and rs10114470 polymorphisms 
Table 4. Genotype and allele distributions in patients and controls. *: Represents the wild type

\begin{tabular}{|c|c|c|c|c|c|c|c|c|c|}
\hline Genotypes & $\begin{array}{c}\mathrm{HC}(\mathrm{N}=517) \\
\mathrm{N}(\%)\end{array}$ & $\begin{array}{l}\mathrm{CD}(\mathrm{N}=179) \\
\mathrm{N}(\%)\end{array}$ & $P$ & OR & $95 \% \mathrm{CI}$ & $\begin{array}{l}\text { UC }(\mathrm{N}=202) \\
\mathrm{N}(\%)\end{array}$ & $P$ & OR & $95 \% \mathrm{CI}$ \\
\hline \multicolumn{10}{|l|}{$r s 1250569$} \\
\hline $\mathrm{AA}+\mathrm{AG}$ & $376(72.73)$ & 141 (78.77) & \multirow[t]{2}{*}{0.111} & \multirow[t]{2}{*}{1.391} & \multirow[t]{2}{*}{$0.926-2.091$} & $150(74.26)$ & \multirow[t]{2}{*}{0.677} & \multirow[t]{2}{*}{1.082} & \multirow[t]{2}{*}{$0.747-1.566$} \\
\hline $\begin{array}{l}\mathrm{GG}^{*} \\
\text { Allele }\end{array}$ & $141(27.27)$ & $38(21.23)$ & & & & $52(25.74)$ & & & \\
\hline A & $505(48.84)$ & $197(55.03)$ & \multirow[t]{3}{*}{0.044} & \multirow[t]{3}{*}{1.282} & \multirow[t]{3}{*}{$1.007-1.632$} & $210(51.98)$ & \multirow[t]{3}{*}{0.284} & \multirow[t]{3}{*}{1.134} & \multirow[t]{3}{*}{$0.901-1.427$} \\
\hline $\mathrm{G}^{*}$ & $529(51.16)$ & $161(44.97)$ & & & & $194(48.02)$ & & & \\
\hline rs1042522 & & & & & & & & & \\
\hline $\mathrm{GG}+\mathrm{CG}$ & $416(80.46)$ & 138 (77.09) & \multirow[t]{3}{*}{0.335} & \multirow[t]{3}{*}{0.817} & \multirow[t]{3}{*}{$0.542-1.232$} & $173(85.64)$ & \multirow[t]{3}{*}{0.105} & \multirow[t]{3}{*}{1.448} & \multirow[t]{3}{*}{$0.924-2.270$} \\
\hline $\mathrm{CC}^{*}$ & $101(19.54)$ & $41(22.91)$ & & & & $29(14.36)$ & & & \\
\hline Allele & & & & & & & & & \\
\hline G & $583(56.38)$ & $201(56.15)$ & \multirow{2}{*}{0.938} & \multirow{2}{*}{0.990} & \multirow{2}{*}{$0.777-1.262$} & $233(57.67)$ & \multirow{3}{*}{0.657} & \multirow{3}{*}{1.054} & \multirow{3}{*}{$0.835-1.330$} \\
\hline$C^{*}$ & $451(43.62)$ & $157(43.85)$ & & & & $171(42.33)$ & & & \\
\hline rs 10114470 & & & & & & & & & \\
\hline $\mathrm{TT}+\mathrm{CT}$ & $400(77.37)$ & $117(65.36)$ & \multirow{3}{*}{0.002} & \multirow{3}{*}{0.552} & \multirow{3}{*}{$0.381-0.799$} & $157(77.72)$ & \multirow{3}{*}{0.919} & \multirow{3}{*}{1.021} & \multirow{3}{*}{$0.691-1.508$} \\
\hline $\mathrm{CC}^{*}$ & $117(22.63)$ & $62(34.64)$ & & & & $45(22.28)$ & & & \\
\hline Allele & & & & & & & & & \\
\hline $\mathrm{T}$ & $532(51.45)$ & $151(42.18)$ & \multirow{2}{*}{0.002} & \multirow{2}{*}{0.688} & \multirow{2}{*}{$0.540-0.877$} & $204(50.50)$ & \multirow{2}{*}{0.745} & 0.962 & $0.765-1.211$ \\
\hline $\mathrm{C}^{*}$ & $502(48.55)$ & $207(57.82)$ & & & & $200(49.50)$ & & & \\
\hline
\end{tabular}

Table 5. Genotype and phenotype distributions for patients and controls

\begin{tabular}{|c|c|c|c|c|c|c|c|c|c|c|c|}
\hline \multirow[t]{2}{*}{ Phenotype } & \multicolumn{4}{|c|}{ rs1250569 } & \multicolumn{3}{|c|}{ rs1042522 } & \multicolumn{4}{|c|}{ rs10114470 } \\
\hline & \multicolumn{3}{|c|}{$\mathrm{AA}, \mathrm{AG}$ vs GGP } & $\mathrm{OR}(95 \% \mathrm{CI})$ & \multicolumn{2}{|c|}{ GG,CG vs CC P } & $\mathrm{OR}(95 \% \mathrm{CI})$ & \multicolumn{2}{|c|}{ TT,CT vs CC } & $P$ & $\mathrm{OR}(95 \% \mathrm{CI})$ \\
\hline HC (N) & \multicolumn{4}{|c|}{ (376) (141) } & \multicolumn{3}{|c|}{$(416)(101)$} & $(400)$ & \multicolumn{2}{|c|}{ (117) } & \\
\hline $\mathrm{CD}(\mathrm{N})$ & \multicolumn{4}{|c|}{$(141)(38)$} & \multicolumn{3}{|c|}{$(138)(41)$} & (117) & \multicolumn{2}{|l|}{ (62) } & \\
\hline \multicolumn{12}{|l|}{ Age at diagnosis (yr) } \\
\hline$<17$ & 16 & 0 & 0.03 & $\begin{array}{l}321.375(1.304- \\
1.450)\end{array}$ & 10 & 6 & $\begin{array}{l}0.1470 .405(0.144- \\
.139)\end{array}$ & 8 & 6 & 0.147 & $0.390(0.133-1.147)$ \\
\hline $17-40$ & 96 & 29 & 0.354 & $\begin{array}{l}541.241(0.785- \\
1.963)\end{array}$ & 96 & 29 & $\begin{array}{l}0.3600 .804(0.503- \\
1.284)\end{array}$ & 78 & 43 & 0.003 & $0.531(0.347-0.812)$ \\
\hline$>40$ & 29 & 9 & 0.631 & $\begin{array}{l}11.208(0.558- \\
2.616)\end{array}$ & 32 & 6 & $\begin{array}{c}0.5721 .295(0.527- \\
3.181)\end{array}$ & 31 & 13 & 0.297 & $0.698(0.354-1.376)$ \\
\hline \multicolumn{12}{|l|}{ Site of disease } \\
\hline L1 lleal & 35 & 12 & 0.797 & $\begin{array}{l}771.094(0.552- \\
2.167)\end{array}$ & 40 & 10 & $\begin{array}{l}0.9370 .971(0.470- \\
2.008)\end{array}$ & 26 & 20 & 0.002 & $0.380(0.205-0.706)$ \\
\hline L2 Colonic & 46 & 10 & 0.129 & $\begin{array}{l}291.725(0.847- \\
3.511)\end{array}$ & 38 & 10 & $\begin{array}{c}0.8290 .923(0.445- \\
1.914)\end{array}$ & 38 & 20 & 0.045 & $0.556(0.311-0.992)$ \\
\hline L3 Ileocolitis & 57 & 14 & 0.176 & $\begin{array}{l}761.527(0.825- \\
2.826)\end{array}$ & 56 & 19 & $\begin{array}{c}0.2430 .716(0.407- \\
1.258)\end{array}$ & 51 & 20 & 0.301 & $0.746(0.427-1.301)$ \\
\hline L4 Upper GI & 3 & 2 & 0.896 & $\begin{array}{l}\begin{array}{l}36.563(0.093- \\
3.402)\end{array} \\
\end{array}$ & 4 & 2 & $\begin{array}{l}0.971(0.107- \\
8.783)\end{array}$ & 2 & 2 & 0.225 & $0.293(0.041-2.099)$ \\
\hline \multicolumn{12}{|l|}{ Disease behaviour } \\
\hline $\begin{array}{l}\text { B1non-stricturing non- } \\
\text { penetrating }\end{array}$ & 95 & 24 & 0.111 & $\begin{array}{l}11 \text { 1.484(0.911- } \\
2.418)\end{array}$ & 91 & 28 & $\begin{array}{c}0.3290 .789(0.490- \\
1.270)\end{array}$ & 85 & 36 & 0.099 & $0.691(0.444-1.073)$ \\
\hline B2 Stricturing & 29 & 10 & 0.825 & $\begin{array}{l}251.088(0.517- \\
2.289)\end{array}$ & 31 & 8 & $\begin{array}{c}0.8820 .941(0.420- \\
2.109)\end{array}$ & 21 & 14 & 0.019 & $0.439(0.216-0.890)$ \\
\hline B3 Penetrating & 17 & 4 & 0.405 & $\begin{array}{l}51.594(0.527- \\
4.818)\end{array}$ & 16 & 5 & $\begin{array}{c}0.8390 .777(0.278- \\
2.171)\end{array}$ & 11 & 12 & 0.001 & $0.268(0.115-0.623)$ \\
\hline Perianal disease & 21 & 5 & 0.367 & $\begin{array}{l}571.575(0.583- \\
4.257)\end{array}$ & 19 & 7 & $\begin{array}{c}0.3570 .659(0.270- \\
1.610)\end{array}$ & 15 & 12 & 0.009 & $0.366(0.167-0.803)$ \\
\hline UC $(\mathrm{N})$ & \multicolumn{4}{|c|}{$(150)(52)$} & \multicolumn{3}{|c|}{$(173)(29)$} & (157) & \multicolumn{2}{|l|}{ (45) } & \\
\hline \multicolumn{12}{|l|}{ Age at diagnosis (yr) } \\
\hline$<17$ & 4 & 0 & 0.51 & $\begin{array}{l}1.375(1.304- \\
1.450)\end{array}$ & 3 & 1 & $\begin{array}{c}0.5830 .728(0.075- \\
7.075)\end{array}$ & 3 & 0 & 1 & $1.293(1.234-1.354)$ \\
\hline $17-40$ & 72 & 30 & 0.65 & $\begin{array}{l}990.900(0.564- \\
1.437)\end{array}$ & 83 & 19 & $\begin{array}{c}0.8321 .061(0.616- \\
1.827)\end{array}$ & 86 & 23 & 0.728 & $1.094(0.661-1.811)$ \\
\hline$>40$ & 74 & 22 & 0.375 & $\begin{array}{l}751.261(0.755- \\
2.109)\end{array}$ & 87 & 9 & $\begin{array}{c}0.0172 .347(1.143- \\
4.821)\end{array}$ & 68 & 22 & 0.705 & $0.904(0.536-1.525)$ \\
\hline \multicolumn{12}{|l|}{ Disease location } \\
\hline E1 Proctitis & 19 & 6 & 0.719 & $\begin{array}{l}191.188(0.465- \\
3.034)\end{array}$ & 21 & 4 & $\begin{array}{c}0.8591 .275(0.428- \\
3.795)\end{array}$ & 20 & 4 & 0.493 & $1.463(0.490-4.363)$ \\
\hline E2 Left-sided & 61 & 17 & 0.307 & $\begin{array}{l}7.346(0.760- \\
2.382)\end{array}$ & 65 & 13 & $\begin{array}{l}0.5481 .214(0.644- \\
2.288)\end{array}$ & 64 & 18 & 0.891 & $1.040(0.593-1.824)$ \\
\hline E3 Extensive & 70 & 29 & 0.68 & $\begin{array}{l}3.905(0.563- \\
1.454)\end{array}$ & 87 & 12 & $\begin{array}{c}0.0811 .760(0.927- \\
3.343)\end{array}$ & 73 & 23 & 0.776 & $0.928(0.556-1.549)$ \\
\hline
\end{tabular}

and UC phenotypes. Additionally, there was no association between the rs1042522 polymorphism and CD or UC phenotypes. 
A

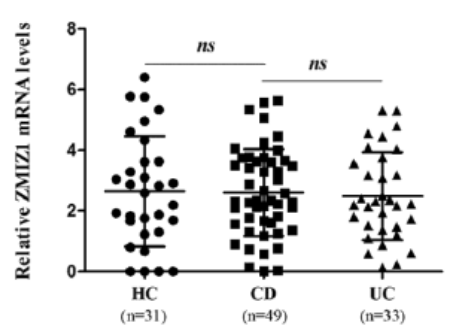

C

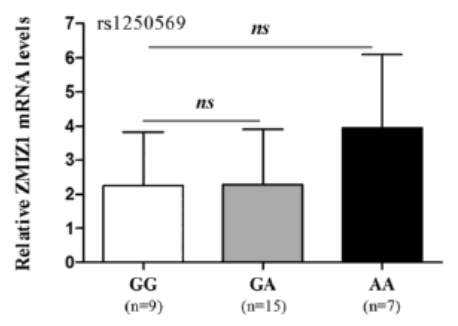

B

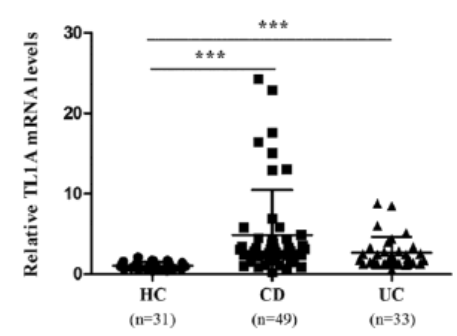

D

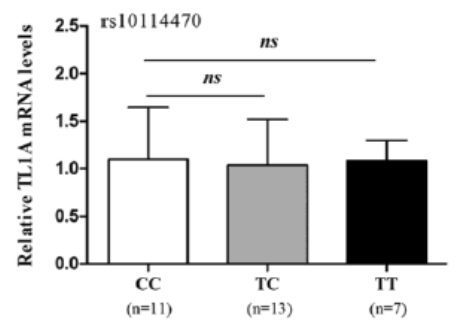

Fig. 1. ZMIZ1 and TL1A expression in human peripheral blood. Blood samples were collected from 31 healthy controls, $49 \mathrm{CD}$ patients and $33 \mathrm{UC}$ patients. A: ZMIZ1 mRNA levels in peripheral blood. B: TL1A mRNA levels in peripheral blood. The 31 healthy controls were subgrouped according to their genotypes for ZMIZ1 and TL1A, and the effects of rs1250569 variants on ZMIZ1 expression (C) and the effects of rs10114470 variants on TL1A expression (D) are presented. ${ }^{* * *} p<0.001$ vs. HC (healthy controls).

IBD patients possessed higher levels of TL1A other than ZMIZ1 in peripheral blood

Our sequencing data demonstrated that rs1250569 (ZMIZ1) and rs10114470 (TL1A) are associated with the development of IBD. We used qRT-PCR to further analyse the systematic expression of the two genes in blood samples obtained from IBD patients. A total of $49 \mathrm{CD}, 33 \mathrm{UC}$, and 31 healthy controls were included in this analysis. The enrolled subjects were selected from individuals for whom we could obtain genotyping data. The primers used in these reactions are listed in Table 2. We found that ZMIZ1 expression in the blood was lower in the CD $(2.61 \pm 1.43)$ and UC $(2.49 \pm 1.45)$ groups than in healthy controls $(2.64 \pm 1.82)$, but this difference was not statistically significant ( $p=0.92$ for $\mathrm{CD} ; p=0.69$ for UC) (Fig. 1A). Both the CD and the UC group possessed higher levels of TL1A mRNA than the healthy controls $(4.88 \pm 5.60 v s .1 .07 \pm 0.41, p<0.001$ for CD; $2.67 \pm 1.94 v s .1 .07 \pm 0.41$, $p<0.001$ for UC) (Fig. 1B).

To further investigate whether variants of the two SNPs affect the mRNA expression of these two genes, we divided the 31 healthy individuals into three groups based on their rs1250569 (ZMIZ1) and rs10114470 (TNFSF15) genotyping data. Our results demonstrate that the rs1250569 and rs10114470 variants did not influence gene expression (Fig. 1C and 1D).

IBD patients possessed increased ZMIZ1 and TL1A levels in the gut

Because IBD is an inflammatory disease that primarily affects the gut, we next sought to determine the mRNA and protein levels of ZMIZ1 and TL1A in colonic biopsies obtained from IBD patients. Inflamed colon samples were obtained from 17 CD and 17 UC patients, and non-inflamed colon tissues were obtained from a region 20 centimetres away from the inflamed tissues in 8 patients with polyps or neoplasms (NIBDs) who were included in this study. However, unlike their expression in the blood, we observed markedly higher ZMIZ1 mRNA levels in CD and UC tissues than in healthy control tissues (3.43 \pm 2.20 vs. $1.20 \pm$ 1.25, $p<0.05$ for CD; $3.01 \pm 2.25$ vs. $1.20 \pm 1.25, p<0.05$ for UC) (Fig. 2A). Consistent with its expression in the blood, TL1A levels were also dramatically higher in intestinal tissues 


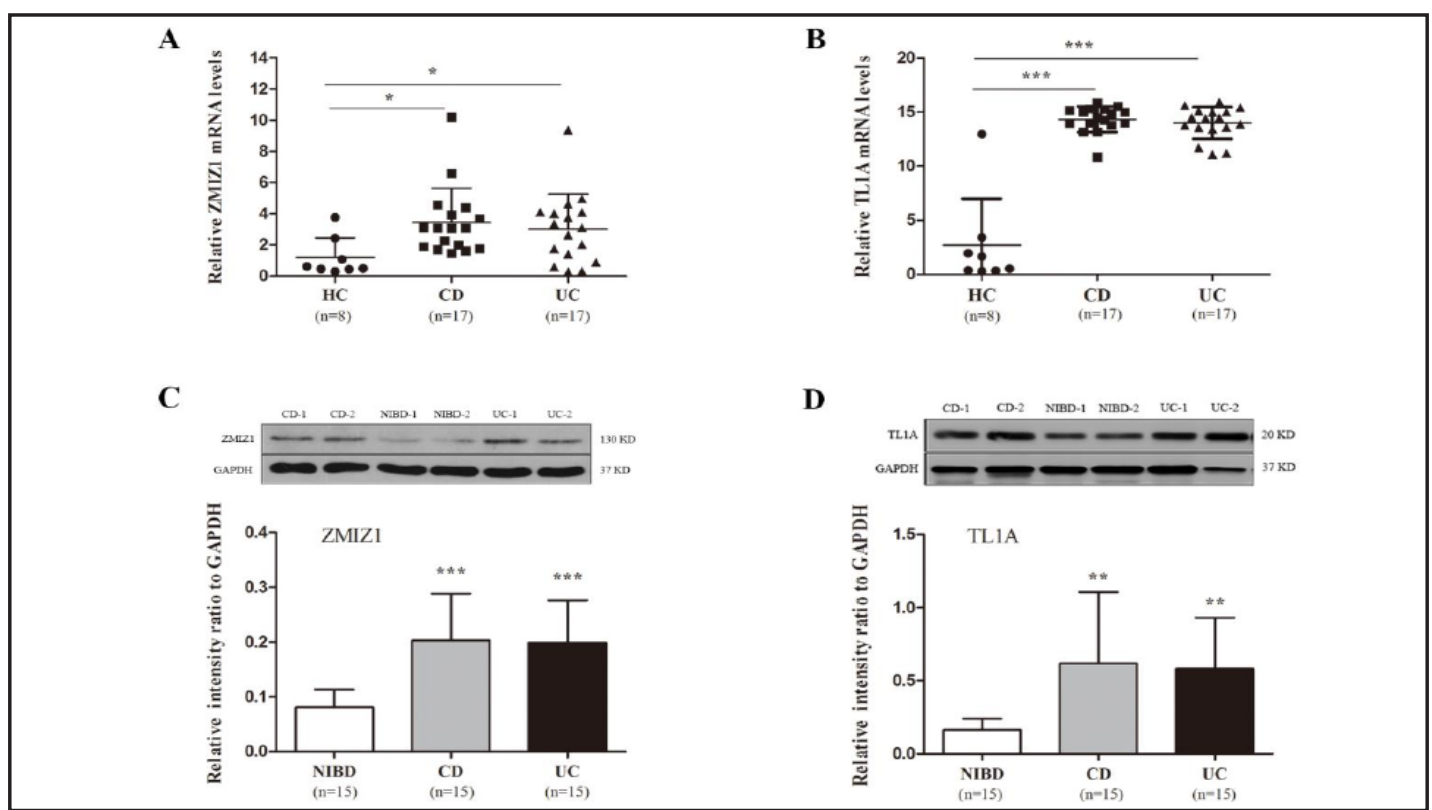

Fig. 2. ZMIZ1 and TL1A expression in the human gut. Colon biopsies were recruited from 8 healthy controls and 17 CD and 17 UC patients. A: ZMIZ1 mRNA levels in the gut. B: TL1A mRNA levels in the gut. Total protein was extracted from another 15 normal colon tissues that were obtained 20 centimetres away from polyps or neoplasms (NIBD) and inflammatory biopsies that were obtained from 15 CD and 15 UC patients. C: Representative results of western blots and quantitation of band intensities for ZMIZ1. D: Representative results of western blots and quantitation of band intensities for TL1A. ${ }^{*} p<0.05,{ }^{* *} p<0.01,{ }^{* * *} p<0.001$ vs. HC (healthy controls) or NIBD (non-IBD).

Fig. 3. In situ expression of ZMIZ1 in the human gut. A: Immunohis to chemistry for ZMIZ1 was performed on 3 $\mu \mathrm{m}$-thick colon sections, and representative pictures are shown. Scale bar $=50 \mu \mathrm{m}$ for the left column and $20 \mu \mathrm{m}$ for the right column. B: Negative control staining for immunohis to -

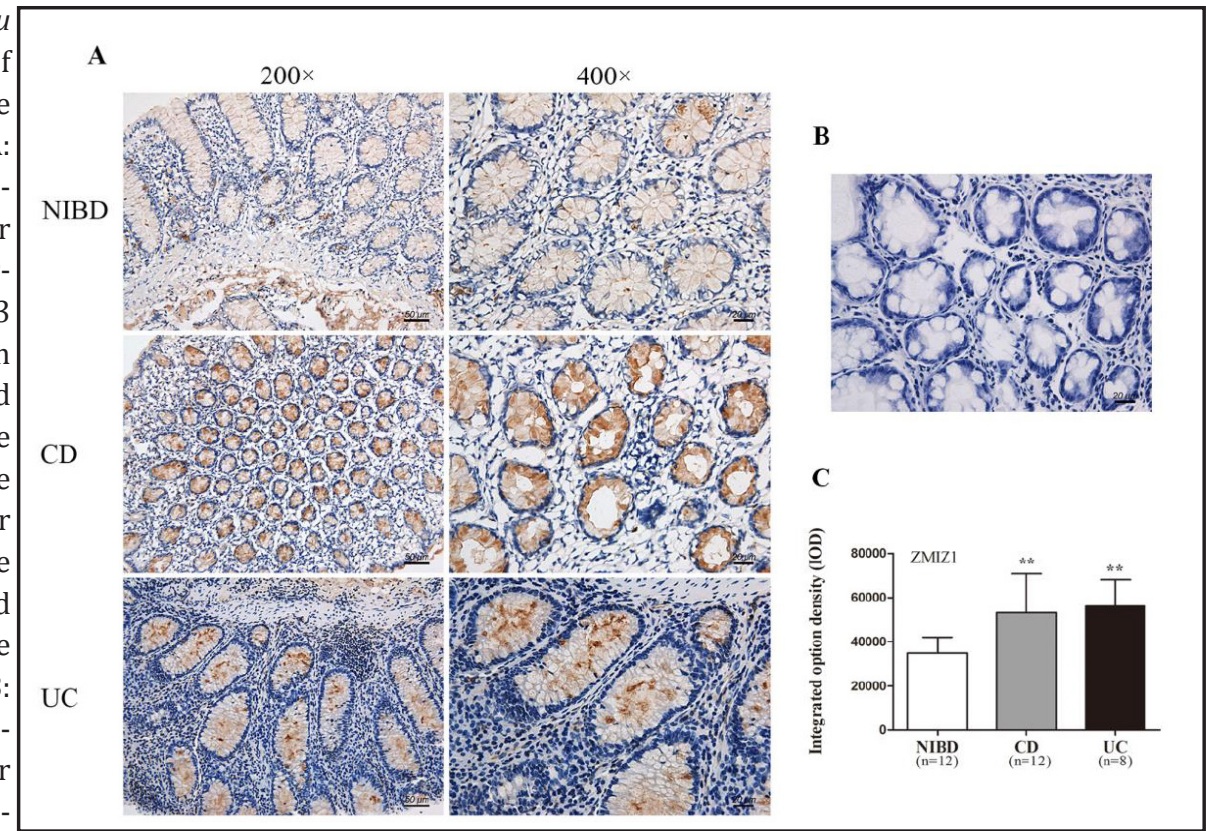
chemistry. Sections were treated with PBS instead of the primary antibody. Scale bar $=20 \mu \mathrm{m}$. C: Quantification of ZMIZ1 ${ }^{+}$cells in intestinal biopsies. A total of 12 NIBD, 12 CD and 8 UC samples were included. ${ }^{* *} p<$ 0.01 vs. NIBD (non-IBD).

obtained from CD and UC patients than in healthy controls $(14.34 \pm 1.20$ vs. $2.70 \pm 4.29$, $p<0.001$ for CD; $13.99 \pm 1.47$ vs. $2.70 \pm 4.29, p<0.001$ for UC) (Fig. $2 B$ ). 
Fig. 4. Colitis-associated manifestations in a DSS-induced acute colitis model. A: Changes in body weight are shown as percentages. B: Change in DAI scores. C: Representative photographs of colon lengths obtained from the caecum to the anus on day 7 and statistical analysis of colon length (D). E: Representative histological images (scale bar $=200 \mu \mathrm{m}$ for the left column, $100 \mu \mathrm{m}$ for the middle column, and 50 $\mu \mathrm{m}$ for the right column) on tissues obtained from control mice and DSS-treated mice. F: Histological scores of distal colonic tissue obtained from control and DSS-treated mice. The data are presented as the mean $\pm \mathrm{SD}$. $\mathrm{N}=8$ per group. ${ }^{* *} p$ $<0.01,{ }^{* * *} p<0.001$ vs. control mice.
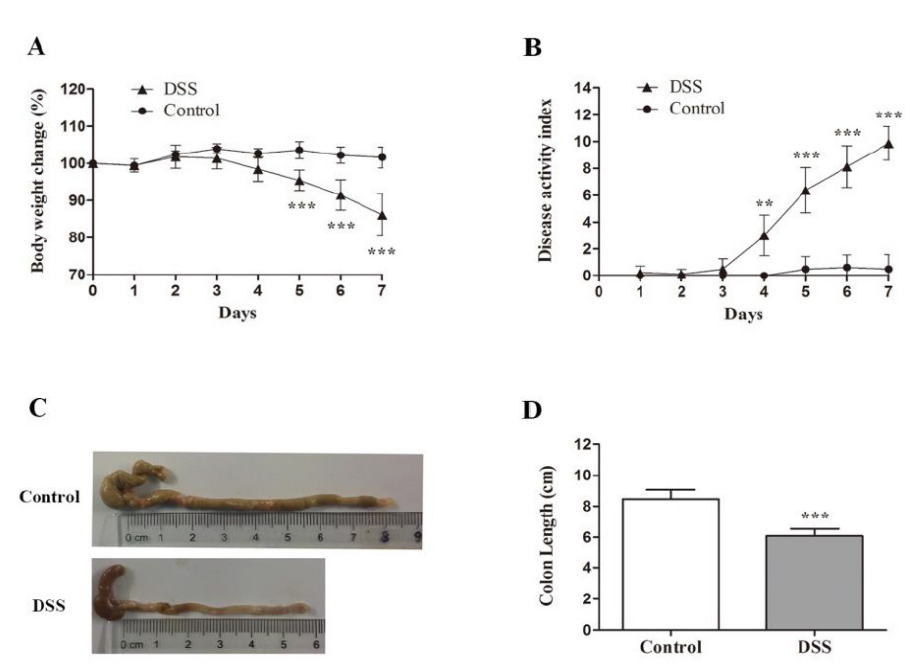

D
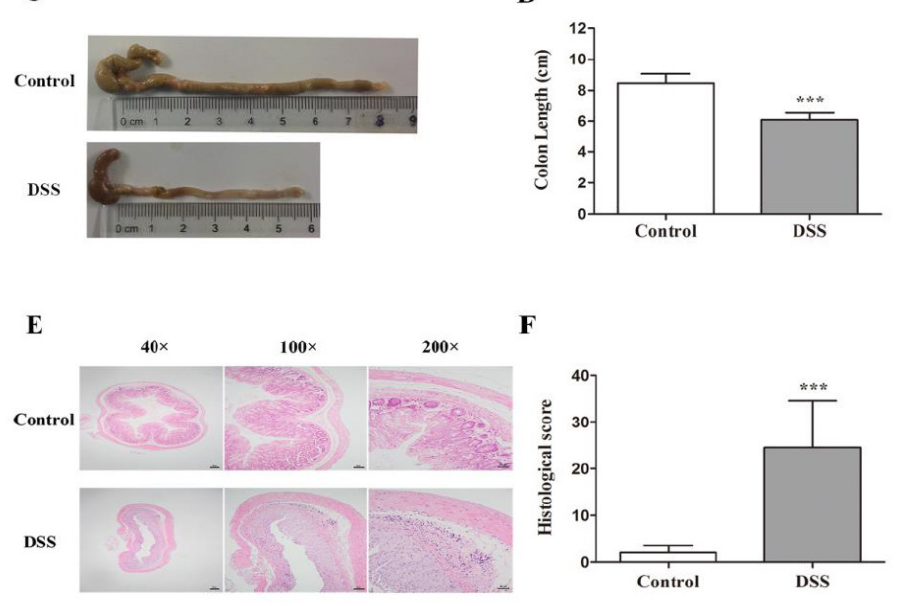

$\mathbf{F}$

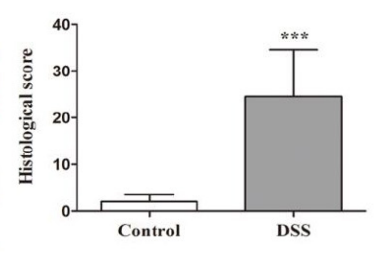

Total protein was extracted from normal colon biopsies obtained from 15 NIBD individuals and inflamed colon tissues obtained from 15 CD and 15 UC patients. Western blot assays revealed that the protein level of ZMIZ1 was significantly higher in both the CD $(0.20 \pm 0.085)$ and UC $(0.20 \pm 0.077)$ groups than in the NIBD group $(0.081 \pm 0.033)$. In both cases, this difference was very significant ( $p<0.001$ for CD, $p<0.001$ for UC) (Fig. 2C). Consistent with previous studies, we observed higher TL1A protein levels in Chinese IBD patients ( $p=0.009$ for CD, $p=0.001$ for UC) (Fig. 2D).

As shown in Fig. 3A, ZMIZ1 was mainly localized in the nucleus and cytoplasm in epithelial cells in the colonic mucosa and inflammatory cells in the lamina propria (LP). Our IOD analysis demonstrated that there were markedly higher numbers of ZMIZ1-positive cells in both CD (53153.34 $\pm 17522.64, p=0.002)$ and UC (56018.04 $\pm 12047.16, p=0.001)$ gut mucosae. In contrast, only a few ZMIZ1-positive cells (34826.88 \pm 7273.47 ) were present in the normal gut specimens (Fig. 3C). Our data demonstrate that ZMIZ1 expression is locally higher in the inflamed intestinal tissues of IBD patients. Furthermore, ZMIZ1 is a novel potential predictive gene for IBD in Chinese populations and that it might play crucial roles in IBD pathogenesis.

\section{Raised ZMIZ1 and TL1A expression in a DSS-induced colitis model}

To further evaluate ZMIZ1 and TL1A expression in experimental colitis, we induced acute colitis in Balb/c mice by administering 4.5\% DSS in their drinking water for 7 days. We found that mice treated with DSS lost significantly more body weight than control mice beginning on day 5 (day 5 : $95.43 \pm 2.74 \%$ vs. $103.59 \pm 2.32 \%, p<0.001$; day $6: 91.50 \pm 4.06 \%$ vs. $102.23 \pm 2.17 \%, p<0.001$ and day $7: 86.13 \pm 5.65 \%$ vs. $101.63 \pm 2.82 \%, p<0.001$ ) (Fig. $4 A)$. In addition, the DAI scores were markedly worse in the colitis mice than in the control mice (day 4, $p=0.001$; day5, $p<0.001$; day 6, $p<0.001$; day7, $p<0.001$ ) (Fig. 4B). Colon length is an additional macroscopic indicator of gut damage, and we found that they were significantly lower in the DSS-treated mice than in control mice $(6.09 \pm 0.45 \mathrm{~cm} v s .8 .46 \pm$ $0.56 \mathrm{~cm}, p<0.001$ ) (Fig. 4C and 4D). Furthermore, we found that administering DSS resulted 
Fig. 5. ZMIZ1 and TL1A expression in a DSS-induced colitis model. Total RNA was extracted from colonic tissues obtained from 8 control mice and 8 experimental mice. A: ZMIZ1 mRNA levels in control mice and DSS-treated mice. B: TL1A mRNA levels in control mice and DSS-treated mice. Total protein was extracted from colon samples obtained from 8 control mice and 8 DSS-treated mice. C: Western blot analysis of the protein abundance of ZMIZ1and TL1A. GAPDH was used as a loading control. D: Statistical analysis of the protein expression of ZMIZ1 and TL1A between control mice and DSS-treated mice. E: Representative pictures of the in situ expression of ZMIZ1 in experimental mice and control mice. Scale bar $=50 \mu \mathrm{m}$ for the left column and $20 \mu \mathrm{m}$ for the right column. $\mathrm{N}=8$ per group.

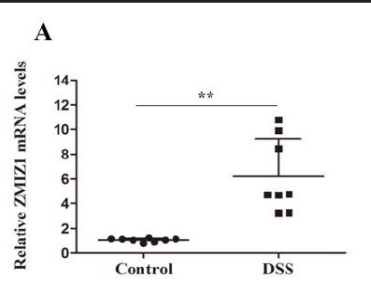

$$
\text { C }
$$
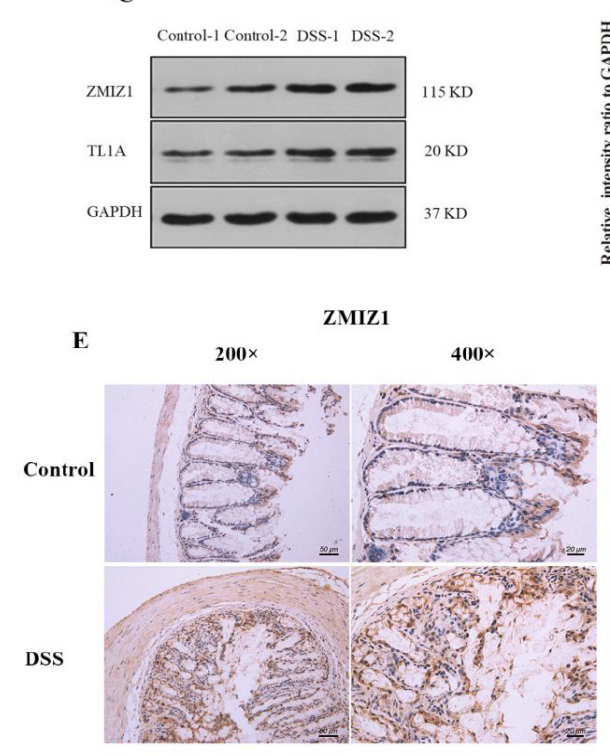
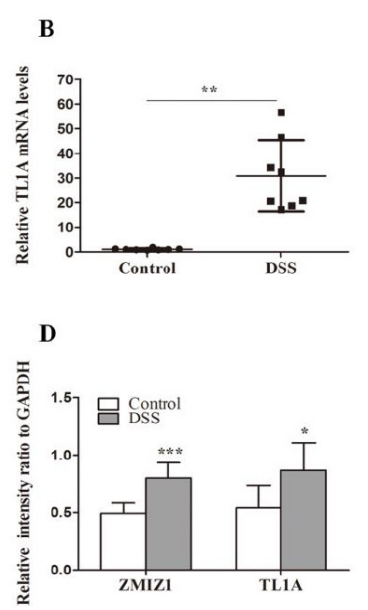

$\mathbf{F}$

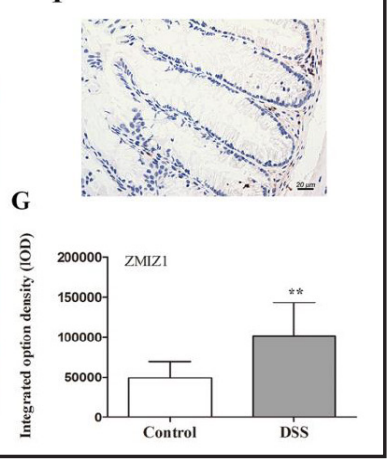
F: Negative control staining for immunohistochemistry. Scale bar $=20 \mu \mathrm{m}$. G: Statistical analysis of ZMIZ1 in situ expression in the two groups of mice. ${ }^{*} p<0.05,{ }^{* *} p<0.01,{ }^{* * *} p<0.001$ vs. control mice.

in the loss of normal colonic architecture and was characterised by epithelial damage and inflammatory cell infiltration. These changes were reflected in the histological scores, which were determined under microscopy (Fig. 4E and 4F). These data showed that our DSSinduced colitis model was successful.

On day 7, the experimental mice and control mice were executed. To investigate ZMIZ1 and TL1A expression, we extracted total mRNA and protein from colon tissues. qRT-PCR was performed using the primers listed in Table 2. Western blot assays were also performed. As shown in Fig. 5A and 5B, ZMIZ1 (6.21 \pm 3.02 vs. $1.01 \pm 0.14, p=0.002)$ and TL1A (30.85 \pm 14.49 vs. $0.45 \pm 0.37, p=0.001)$ mRNA levels were dramatically higher in DSS-treated mice than in control mice. Western blot analyses confirmed the results of qRT-PCR, showing that both ZMIZ1 ( $0.80 \pm 0.13$ vs. $0.49 \pm 0.09, p<0.001)$ and TL1A $(0.87 \pm 0.24$ vs. $0.54 \pm 0.20, p<$ 0.05 ) were two-fold more abundant in DSS-administered mice than in control mice (Fig. 5C, 5D). The in situ expression of ZMIZ1 in the colons of experimental mice and control mice was consistent with its expression in humans. Our IOD analysis demonstrated that DSS-treated mice expressed much more ZMIZ1 than control mice (101568 \pm 41402 vs. $49447 \pm 20121, p$ $=0.006$ ) (Fig. 5E and 5G).

\section{Discussion}

Many SNPs have been shown to be associated with the development of IBD. In this study, we demonstrate that three novel susceptible loci that were recently discovered in Korean and Canadian populations are also present in the Chinese Han population. Of the 


\section{Cellular Physiology Cell Physiol Biochem 2017;41:2077-2090 \\ \begin{tabular}{l|l} 
DOI: 10.1159/000475439 & Ond Biochemistry 2017 The Author(s). Published by S. Karger AG, Basel \\
www.karger.com/cpb
\end{tabular} \\ Lan et al.: Two Novel Susceptible Loci for IBD in a Chinese Han Population}

three loci investigated, rs1250569 (ZMIZ1) and rs10114470 (TL1A) were found to increase susceptibility to IBD in China, whereas rs1042522 (TP53) did not. Moreover, ZMIZ1 and TL1A were expressed at higher levels in IBD than in control samples, further confirming the notion that these genes play critical roles in IBD pathogenesis. In vivo, we used a DSSinduced acute mouse colitis model to show that ZMIZ1 and TL1A are significantly increased in mice with colitis.

ZMIZ1 (also ZIMP10) is a PIAS (protein inhibitor of activated STAT)-like protein [24] that shares a ring finger domain named Miz (msx-interacting zinc finger) with other PIAS proteins [25]. This gene has been shown to act as a transcriptional co-regulator of the activation of TP53 and the transforming growth factor-beta (TGF- $\beta$ )/mothers against decapentaplegic homologue (Smad) signalling pathways, possibly via chromatin remodelling [26-28].

Many genetic variants of ZMIZ1 have been found to be associated with IBD. rs1250550 was found to be an early-onset IBD-specific SNP in the region of ZMIZ1 [29, 30]. rs1250569 which lies within ZMIZ1, was also found to be a susceptibility locus for CD in Koreans [9]. Our data support the notion that there is an association between rs1250569 and susceptibility to early-onset Crohn's disease. Studies regarding the role of ZMIZ1 in IBD pathogenesis have primarily focused on SNPs. Few studies have reported its expression in IBD patients. Our study provides the first line of evidence that ZMIZ1 is locally increased in the inflamed gut tissues of IBD patients other than systemically elevated in the blood. Additionally, we further verified that it is expressed at higher levels in mice with DSS-induced colitis. Furthermore, although our sequencing data showed that there was no relationship between rs1250569 and UC, we observed that ZMIZ1 is increased in gut samples obtained from UC patients.

As a downstream of ZMIZ1, TGF- $\beta$ is a pleiotropic cytokine with multiple immunosuppressive properties. Both immune cells (e.g., T cells, macrophages, and dendritic cells) and non-immune cells (e.g., stromal and epithelial cells) produce TGF- $\beta 1$ in the guts of humans and mice, and virtually all intestinal mucosal cells are targeted by this cytokine [31, 32]. TGF- $\beta$ inhibits many biological processes, including T cell proliferation, the differentiation of T cells into cytotoxic T lymphocytes, and helper T-cells and T-cell stimulatory functions of antigen-presenting cells $[33,34]$. TGF- $\beta$ has also been found to promote the differentiation of regulatory T cells in vitro [35]. Hence, among the roles that have been identified for ZMIZ1, its role in modulating TGF- $\beta$ is exciting for IBD pathogenesis. Based on these findings, we hypothesized that ZMIZ1 might exert its regulatory effect on gut inflammation by modulating TGF- $\beta$ expression. Further investigations are needed to verify our hypothesis.

TP53 is a tumour suppressor gene and that has been associated with a large variety of tumours [36-38]. Few articles have described the relationship between IBD and TP53, and most of these have focused on UC. Hussain et al. [39] showed that the rates of G-to-A alteration in codon 248 and C-to-T alteration at the third base of codon 247 of TP53 were much higher in UC cases than in controls. In 2003, Fujii et al. investigated mutations in TP53 exons 5-8 in UC-associated neoplasias and inflammatory regenerative epithelia and found that they accounted for $95.2 \%$ of the former but few of the latter [40]. These data indicate that mutations in TP53 contribute to the morbidity and biological characteristics associated with UC. A recent study of a Canadian population found that TP53 polymorphisms are also associated with CD [10]. Our study represents the first analysis of TP53 (Arg72Pro) polymorphisms in IBD patients in a Chinese population. In contrast to the study performed by Volodko $\mathrm{N}$ et al. [10], we failed to find a significant relationship between rs1042522 and IBD. One potential reason for this discrepancy is that the samples included in these two studies were obtained from different ethnic groups who resided in different geographic regions.

As a key regulator of inflammatory pathways, TL1A plays critical roles in IBD development. Significantly higher levels of TL1A expression have been observed in IBD patients in many populations, yet only limited data are available for the Chinese Han population [41-43]. Our laboratory previously reported that there are higher levels of TL1A mRNA and soluble protein in the serum and gut mucosa, respectively, of UC patients [44]. In this study, we have corroborated these findings by showing that TL1A levels are higher 
in both CD and UC patients. This is the first evidence to show the TL1A mRNA and protein expression are increased both locally and systemically in Chinese CD patients.

In conclusion, our data support the notion that there is an association between two extensively studied IBD-associated genetic variants (rs1250569 and rs10114470) and IBD development in a Chinese Han population. We found that the levels of ZMIZ1 and TL1A were higher in samples obtained from both IBD patients and mice with experimentally induced colitis. Still, further studies are required to determine the mechanism by which ZMIZ1 regulates IBD and its precise role in inflammation.

\section{Acknowledgements}

The authors thank all individuals who participated in this study. This work was supported by grants from the National Natural Science Foundation of China (grant numbers: 81270467 and 81470823 ).

\section{Disclosure Statement}

The authors have no financial conflicts of interest to declare.

\section{References}

1 Podolsky DK: Inflammatory bowel disease. N Engl J Med 2002;347:417-429.

2 Prideaux L, Kamm MA, De Cruz PP, Chan FK, Ng SC: Inflammatory bowel disease in Asia: a systematic review. J Gastroenterol Hepatol 2012;27:1266-1280.

-3 Ahuja V, Tandon RK: Inflammatory bowel disease in the Asia-Pacific area: a comparison with developed countries and regional differences. J Dig Dis 2010;11:134-147.

-4 Xavier RJ, Podolsky DK: Unravelling the pathogenesis of inflammatory bowel disease. Nature 2007;448:427-434.

5 Maloy KJ, Powrie F: Intestinal homeostasis and its breakdown in inflammatory bowel disease. Nature 2011;474:298-306.

6 Cleynen I, Vazeille E, Artieda M, Verspaget HW, Szczypiorska M, Bringer MA, Lakatos PL, Seibold F, Parnell K, Weersma RK, Mahachie John JM, Morgan-Walsh R, Staelens D, Arijs I, De Hertogh G, Muller S, Tordai A, Hommes DW, Ahmad T, Wijmenga C, Pender S, Rutgeerts P, Van Steen K, Lottaz D, Vermeire S, DarfeuilleMichaud A: Genetic and microbial factors modulating the ubiquitin proteasome system in inflammatory bowel disease. Gut 2014;63:1265-1274.

7 Anderson CA, Boucher G, Lees CW, Franke A, D'Amato M, Taylor KD, Lee JC, Goyette P, Imielinski M, Latiano A, Lagace C, Scott R, Amininejad L, Bumpstead S, Baidoo L, Baldassano RN, Barclay M, Bayless TM, Brand S, Buning C, Colombel JF, Denson LA, de Vos M, Dubinsky M, Edwards C, Ellinghaus D, Fehrmann RS, Floyd JA, Florin T, Franchimont D, Franke L, Georges M, Glas J, Glazer NL, Guthery SL, Haritunians T, Hayward NK, Hugot JP, Jobin G, Laukens D, et al.: Meta-analysis identifies 29 additional ulcerative colitis risk loci, increasing the number of confirmed associations to 47. Nat Genet 2011;43:246-252.

-8 Franke A, McGovern DP, Barrett JC, Wang K, Radford-Smith GL, Ahmad T, Lees CW, Balschun T, Lee J, Roberts R, Anderson CA, Bis JC, Bumpstead S, Ellinghaus D, Festen EM, Georges M, Green T, Haritunians T, Jostins L, Latiano A, Mathew CG, Montgomery GW, Prescott NJ, Raychaudhuri S, Rotter JI, Schumm P, Sharma Y, Simms LA, Taylor KD, Whiteman D, Wijmenga C, Baldassano RN, Barclay M, Bayless TM, Brand S, Buning C, Cohen A, Colombel JF, et al.: Genome-wide meta-analysis increases to 71 the number of confirmed Crohn's disease susceptibility loci. Nat Genet 2010;42:1118-1125.

-9 Yang SK, Hong M, Choi H, Zhao W, Jung Y, Haritunians T, Ye BD, Kim KJ, Park SH, Lee I, Kim WH, Cheon JH, Kim YH, Jang BI, Kim HS, Choi JH, Koo JS, Lee JH, Jung SA, Shin HD, Kang D, Youn HS, Taylor KD, Rotter JI, Liu J, McGovern DP, Song K: Immunochip analysis identification of 6 additional susceptibility loci for Crohn's disease in Koreans. Inflamm Bowel Dis 2015;21:1-7. 


\section{Cellular Physiology Cell Physiol Biochem 2017;41:2077-2090

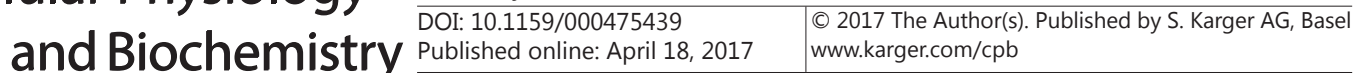

Lan et al.: Two Novel Susceptible Loci for IBD in a Chinese Han Population

10 Volodko N, Salla M, Eksteen B, Fedorak RN, Huynh HQ Baksh S: TP53 codon 72 Arg/Arg polymorphism is associated with a higher risk for inflammatory bowel disease development. World J Gastroenterol 2015;21:10358-10366.

11 Yamazaki K, McGovern D, Ragoussis J, Paolucci M, Butler H, Jewell D, Cardon L, Takazoe M, Tanaka T, Ichimori T, Saito S, Sekine A, Iida A, Takahashi A, Tsunoda T, Lathrop M, Nakamura Y: Single nucleotide polymorphisms in TNFSF15 confer susceptibility to Crohn's disease. Hum Mol Genet 2005;14:3499-3506.

12 Yang SK, Hong M, Zhao W, Jung Y, Baek J, Tayebi N, Kim KM, Ye BD, Kim KJ, Park SH, Lee I, Lee EJ, Kim WH, Cheon JH, Kim YH, Jang BI, Kim HS, Choi JH, Koo JS, Lee JH, Jung SA, Lee YJ, Jang JY, Shin HD, Kang D, Youn HS, Liu J, Song K: Genome-wide association study of Crohn's disease in Koreans revealed three new susceptibility loci and common attributes of genetic susceptibility across ethnic populations. Gut 2014;63:80-87.

13 Arimura Y, Isshiki H, Onodera K, Nagaishi K, Yamashita K, Sonoda T, Matsumoto T, Takahashi A, Takazoe M, Yamazaki K, Kubo M, Fujimiya M, Imai K, Shinomura Y: Characteristics of Japanese inflammatory bowel disease susceptibility loci. J Gastroenterol 2014;49:1217-1230.

14 Hong SN, Park C, Park SJ, Lee CK, Ye BD, Kim YS, Lee S, Chae J, Kim JI, Kim YH: Deep resequencing of 131 Crohn's disease associated genes in pooled DNA confirmed three reported variants and identified eight novel variants. Gut 2016;65:788-796.

15 Kakuta Y, Kinouchi Y, Negoro K, Takahashi S, Shimosegawa T: Association study of TNFSF15 polymorphisms in Japanese patients with inflammatory bowel disease. Gut 2006;55:1527-1528.

16 Tremelling M, Berzuini C, Massey D, Bredin F, Price C, Dawson C, Bingham SA, Parkes M: Contribution of TNFSF15 gene variants to Crohn's disease susceptibility confirmed in UK population. Inflamm Bowel Dis 2008;14:733-737.

17 Baskaran K, Pugazhendhi S, Ramakrishna BS: Protective association of tumor necrosis factor superfamily 15 (TNFSF15) polymorphic haplotype with ulcerative colitis and Crohn's disease in an Indian population. PLoS One 2014;9:e114665.

18 General Assembly of the World Medical Association: World medical association declaration of Helsinki: ethical principles for medical research involving human subjects. J Am Coll Dent 2014;81:14-18.

19 Stange EF, Travis SP, Vermeire S, Reinisch W, Geboes K, Barakauskiene A, Feakins R, Flejou JF, Herfarth H, Hommes DW, Kupcinskas L, Lakatos PL, Mantzaris GJ, Schreiber S, Villanacci V, Warren BF: European evidence-based consensus on the diagnosis and management of ulcerative colitis: definitions and diagnosis. J Crohns Colitis 2008;2:1-23.

20 Silverberg MS, Satsangi J, Ahmad T, Arnott ID, Bernstein CN, Brant SR, Caprilli R, Colombel JF, Gasche C, Geboes K, Jewell DP, Karban A, Loftus EV Jr, Pena AS, Riddell RH, Sachar DB, Schreiber S, Steinhart AH, Targan SR, Vermeire S, Warren BF: Toward an integrated clinical, molecular and serological classification of inflammatory bowel disease: report of a working party of the 2005 montreal world congress of gastroenterology. Can J Gastroenterol 2005;19:5A-36A.

-21 Cooper HS, Murthy SN, Shah RS, Sedergran DJ: Clinicopathologic study of dextran sulfate sodium experimental murine colitis. Lab Invest 1993;69:238-249.

-22 Deng L, Huang R, Chen Z, Wu L, Xu DL: A study on polymorphisms of elastin gene in Chinese Han patients with isolated systolic hypertension. Am J Hypertens 2009;22:656-662.

-23 O'Donovan MC, Craddock N, Norton N, Williams H, Peirce T, Moskvina V, Nikolov I, Hamshere M, Carroll L, Georgieva L, Dwyer S, Holmans P, Marchini JL, Spencer CC, Howie B, Leung HT, Hartmann AM, Moller HJ, Morris DW, Shi Y, Feng G, Hoffmann P, Propping P, Vasilescu C, Maier W, Rietschel M, Zammit S, Schumacher J, Quinn EM, Schulze TG, Williams NM, Giegling I, et al.: Identification of loci associated with schizophrenia by genome-wide association and follow-up. Nat Genet 2008;40:1053-1055.

24 Sharma M, Li X, Wang Y, Zarnegar M, Huang CY, Palvimo JJ, Lim B, Sun Z: hZimp10 is an androgen receptor co-activator and forms a complex with SUMO-1 at replication foci. EMBO J 2003;22:6101-6114.

25 Wu L, Wu H, Ma L, Sangiorgi F, Wu N, Bell JR, Lyons GE, Maxson R: Miz1, a novel zinc finger transcription factor that interacts with Msx2 and enhances its affinity for DNA. Mech Dev 1997;65:3-17.

26 Gutierrez L, Zurita M, Kennison JA, Vazquez M: The Drosophila trithorax group gene tonalli (tna) interacts genetically with the Brahma remodeling complex and encodes an SP-RING finger protein. Development 2003;130:343-354.

27 Lee J, Beliakoff J, Sun Z: The novel PIAS-like protein hZimp10 is a transcriptional co-activator of the p53 tumor suppressor. Nucleic Acids Res 2007;35:4523-4534. 


\section{Cellular Physiology Cell Physiol Biochem 2017;41:2077-2090 \begin{tabular}{l|l} 
DOI: 10.1159/000475439 & Ond Biochemistry 2017 The Author(s). Published by S. Karger AG, Basel \\
wwww.karger.com/cpb
\end{tabular}

28 Li X, Thyssen G, Beliakoff J, Sun Z: The novel PIAS-like protein hZimp10 enhances Smad transcriptional activity. J Biol Chem 2006;281:23748-23756.

-29 Jakobsen C, Cleynen I, Andersen PS, Vermeire S, Munkholm P, Paerregaard A, Wewer V: Genetic susceptibility and genotype-phenotype association in 588 Danish children with inflammatory bowel disease. J Crohns Colitis 2014;8:678-685.

-30 Imielinski M, Baldassano RN, Griffiths A, Russell RK, Annese V, Dubinsky M, Kugathasan S, Bradfield JP, Walters TD, Sleiman P, Kim CE, Muise A, Wang K, Glessner JT, Saeed S, Zhang H, Frackelton EC, Hou C, Flory JH, Otieno G, Chiavacci RM, Grundmeier R, Castro M, Latiano A, Dallapiccola B, Stempak J, Abrams DJ, Taylor K, McGovern D, Silber G, Wrobel I, Quiros A, Barrett JC, et al.: Common variants at five new loci associated with early-onset inflammatory bowel disease. Nat Genet 2009;41:1335-1340.

-31 Kulkarni AB, Karlsson S: Transforming growth factor-beta 1 knockout mice. A mutation in one cytokine gene causes a dramatic inflammatory disease. Am J Pathol 1993;143:3-9.

-32 Gorelik L, Flavell RA: Transforming growth factor-beta in T-cell biology. Nat Rev Immunol 2002;2:46-53.

33 Letterio JJ, Roberts AB: Regulation of immune responses by TGF-beta. Annu Rev Immunol 1998;16:137161.

-34 Travis MA, Sheppard D: TGF-beta activation and function in immunity. Annu Rev Immunol 2014;32:51-82.

35 Shen Y, Wei Y, Wang Z, Jing Y, He H, Yuan J, Li R, Zhao Q, Wei L, Yang T, Lu J: TGF-beta regulates hepatocellular carcinoma progression by inducing Treg cell polarization. Cell Physiol Biochem 2015;35:1623-1632.

-36 Otsuki T, Kanno T, Fujita Y, Tabata C, Fukuoka K, Nakano T, Gotoh A, Nishizaki T: A3 adenosine receptormediated p53-dependent apoptosis in Lu-65 human lung cancer cells. Cell Physiol Biochem 2012;30:210220.

-37 Xu Y, Lu S: Metformin inhibits esophagus cancer proliferation through upregulation of USP7. Cell Physiol Biochem 2013;32:1178-1186.

38 Naccarati A, Polakova V, Pardini B, Vodickova L, Hemminki K, Kumar R, Vodicka P: Mutations and polymorphisms in TP53 gene-an overview on the role in colorectal cancer. Mutagenesis 2012;27:211-218.

39 Hussain SP, Amstad P, Raja K, Ambs S, Nagashima M, Bennett WP, Shields PG, Ham AJ, Swenberg JA, Marrogi AJ, Harris CC: Increased p53 mutation load in noncancerous colon tissue from ulcerative colitis: a cancerprone chronic inflammatory disease. Cancer Res 2000;60:3333-3337.

-40 Fujii S, Fujimori T, Chiba T: Usefulness of analysis of p53 alteration and observation of surface microstructure for diagnosis of ulcerative colitis-associated colorectal neoplasia. J Exp Clin Cancer Res 2003;22:107-115.

41 Bamias G, Martin C 3rd, Marini M, Hoang S, Mishina M, Ross WG, Sachedina MA, Friel CM, Mize J, Bickston SJ, Pizarro TT, Wei P, Cominelli F: Expression, localization, and functional activity of TL1A, a novel Th1polarizing cytokine in inflammatory bowel disease. J Immunol 2003;171:4868-4874.

42 Prehn JL, Mehdizadeh S, Landers CJ, Luo X, Cha SC, Wei P, Targan SR: Potential role for TL1A, the new TNF-family member and potent costimulator of IFN-gamma, in mucosal inflammation. Clin Immunol 2004;112:66-77.

43 Kamada N, Hisamatsu T, Honda H, Kobayashi T, Chinen H, Takayama T, Kitazume MT, Okamoto S, Koganei K, Sugita A, Kanai T, Hibi T: TL1A produced by lamina propria macrophages induces Th1 and Th17 immune responses in cooperation with IL-23 in patients with Crohn's disease. Inflamm Bowel Dis 2010;16:568575.

44 Song L, Zhou R, Huang S, Zhou F, Xu S, Wang W, Yi F, Wang X, Xia B: High intestinal and systemic levels of interleukin-23/T-helper 17 pathway in Chinese patients with inflammatory bowel disease. Mediators Inflamm 2013;2013:425915. 